\title{
$\left[{ }^{15} \mathrm{~N}\right]$ Aspartate metabolism in cultured astrocytes
}

\author{
Studies with gas chromatography-mass spectrometry
}

\begin{abstract}
Marc YUDKOFF, ${ }^{*} \ddagger$ Itzhak NISSIM* and David PLEASURE $\dagger$
*Division of Biochemical Development and Molecular Disease, Children's Hospital of Philadelphia, and *Department of Pediatrics and †Department of Neurology, University of Pennsylvania School of Medicine, 34th Street and Civic Center Boulevard, Philadelphia, PA 19104, U.S.A.
\end{abstract}

\begin{abstract}
The metabolism of $2.5 \mathrm{~mm}-\left[{ }^{15} \mathrm{~N}\right]$ aspartate in cultured astrocytes was studied with gas chromatography-mass spectrometry. Three primary metabolic pathways of aspartate nitrogen disposition were identified: (1) transamination with 2-oxoglutarate to form $\left[{ }^{15} \mathrm{~N}\right]$ glutamate, the nitrogen of which subsequently was transferred to glutamine, alanine, serine and ornithine; (2) condensation with IMP in the first step of the purine nucleotide cycle, the aspartate nitrogen appearing as $\left[6-a m i n o-{ }^{15} \mathrm{~N}\right]$ adenine nucleotides; (3) condensation with citrulline to form argininosuccinate, which is cleaved to yield $\left[{ }^{15} \mathrm{~N}\right]$ arginine. Of these three pathways, the formation of arginine was quantitatively the most important, and net nitrogen flux to arginine was greater than flux to other amino acids, including glutamine. Notwithstanding the large amount of $\left[{ }^{15} \mathrm{~N}\right]$ arginine produced, essentially no $\left[{ }^{15} \mathrm{~N}\right]$ urea was measured. Addition of $\mathrm{NaH}^{13} \mathrm{CO}_{3}$ to the astrocyte culture medium was associated with the formation of $\left[{ }^{13} \mathrm{C}\right]$ citrulline, thus confirming that these cells are capable of citrulline synthesis de novo. When astrocytes were incubated with a lower $(0.05 \mathrm{mM})$ concentration of $\left[{ }^{15} \mathrm{~N}\right]$ aspartate, most ${ }^{15} \mathrm{~N}$ was recovered in alanine, glutamine and arginine. Formation of [6-amino$\left.{ }^{15} \mathrm{~N}\right]$ adenine nucleotides was diminished markedly compared with results obtained in the presence of $2.5 \mathrm{~mm}-\left[{ }^{15} \mathrm{~N}\right]$ aspartate.
\end{abstract}

\section{INTRODUCTION}

It is well established that astroglia are an important site of brain glutamate metabolism (Hertz et al., 1983). Considerable evidence suggests that astrocytes also figure prominently in the metabolism of aspartate, another excitatory amino acid (Cooper et al., 1982). Astrocyte uptake of both aspartate and glutamate is mediated by transport systems having identical values for $K_{\mathrm{m}}$ and $V_{\max }$ (Drejer $e t a l ., 1983$ ). The disappearance of aspartate from cultured astrocyte incubation medium is as rapid as that of glutamate, both compounds being utilized more rapidly than other amino acids (Yudkoff et al., 1986). Inhibition of glutamine synthetase, an exclusively astrocytic enzyme (Norenberg, 1979; Norenberg \& Martinez-Hernandez, 1979), by methionine sulphoximine results in the accumulation of aspartate as well as glutamate in brain slices (Nicklas, 1983).

Many details of the metabolic fate of aspartate in astrocytes are undefined. Thus it is uncertain to what extent aspartate nitrogen is transferred via transamination to glutamate, the nitrogen of which astrocytes readily convert into such amino acids as glutamine and alanine (Yudkoff et al., 1986). In the current work we have utilized gas chromatography-mass spectrometry in order to trace the metabolism of $\left[{ }^{15} \mathrm{~N}\right]$ aspartate by cultured astrocytes. We previously utilized this technique to describe the metabolism of $\left[{ }^{15} \mathrm{~N}\right]$ glutamate and ${ }^{15} \mathrm{NH}_{3}$ by these cells (Yudkoff et al., 1983a,b, 1984). The present work confirms our earlier findings regarding the central importance of transamination reactions and glutamine synthesis in astrocyte nitrogen metabolism. In addition, we now report that arginine synthesis is a major metabolic pathway for the disposal of aspartate nitrogen in astrocytes. Another important route of aspartate nitrogen utilization involves condensation with IMP to form adenylosuccinate, this reaction constituting the initial step of the purine nucleotide cycle (Lowenstein, 1972).

\section{MATERIALS AND METHODS}

\section{Materials}

L- $\left[{ }^{15} \mathrm{~N}\right]$ Aspartic acid (98 atom $\%$ excess) was from MSD Ltd. (Montreal, Quebec, Canada). NADH and glutamate dehydrogenase (both freeze-dried) were from Sigma Chemical Co. (St. Louis, MO, U.S.A.). All ion-exchange resins were from Bio-Rad Laboratories (Richmond, CA, U.S.A.). SAX and $\mathrm{C}_{18}$ preparative columns were from J. T. Baker Chemical Co. (Phillipsburg, NJ, U.S.A.). Reagents used for formation of derivatives were from Regis Chemical Co. (Chicago, IL, U.S.A.). o-Phthalaldehyde was from Pierce Chemical Co. (Rockford, IL, U.S.A.). All other reagents were of the highest available grade and were purchased from Fisher Chemical Co. (Silver Springs, MD, U.S.A.).

\section{Preparation of astrocytes}

Astroglia were prepared from neonatal-rat whole forebrains by selection in a serum-free defined medium as described elsewhere (Kim et al., 1983). All experiments were carried out 4 days after the addition of $5 \mu \mathrm{g}$ of partially purified bovine glial growth factor $/ \mathrm{ml}$. The astrocytes were in an almost confluent monolayer at the time of experiment. The cell density was approx. $2 \times 10^{6} /$ dish in sterile Falcon plastic $35 \mathrm{~mm}$ culture dishes. The culture medium $(2 \mathrm{ml})$ was modified Ham's F-12 medium without serum (Kim et al., 1983). Purity of the preparation (always greater than $98 \%$ ) was deter-

$\ddagger$ To whom all correspondence should be addressed, at Children's Hospital of Philadelphia Division of Biochemical Development and Molecular Disease, 34th and Civic Center Boulevard, Philadelphia, PA 19104, U.S.A. 
mined by using indirect immunofluorescence with anti-(glial fibrillary acidic protein) serum.

\section{Incubation with $\left[{ }^{15} \mathrm{~N}\right]$ aspartate and $\mathrm{NaH}^{13} \mathrm{CO}_{3}$}

All experiments were performed with astrocytes that had been 9 days in culture. At the start of the experiment $200 \mu$ l of $27.5 \mathrm{mM}-\mathrm{L}-\left[{ }^{15} \mathrm{~N}\right]$ aspartic acid (98 atom\% excess; final concn. $2.5 \mathrm{~mm}$ ) was added to dishes containing $2 \mathrm{ml}$ of Ham's F-12 medium that had been changed $48 \mathrm{~h}$ earlier. The culture dishes were placed in an incubator at $37^{\circ} \mathrm{C}$ in humidified air. At the indicated times the culture medium was removed, quickly placed in plastic tubes on ice, and analysed for $\left[{ }^{15} \mathrm{~N}\right]$ amino acids and ${ }^{15} \mathrm{NH}_{3}$. The medium was replaced with $2 \mathrm{ml}$ of deionized water at $4{ }^{\circ} \mathrm{C}$ and the bottom of the dish was scraped vigorously with a rubber spatula to liberate the intracellular contents. After being frozen and thawed once to assure complete cell lysis, it was analysed for [6-amino-15 $\mathrm{N}]$ adenine nucleotides.

In a separate series of experiments, the steady-state culture medium was removed and the astrocytes were washed three times with a warmed $\left(37^{\circ} \mathrm{C}\right)$ solution (pH 7.4) containing $138 \mathrm{~mm}-\mathrm{NaCl}, 5 \mathrm{~mm}-\mathrm{KCl}, 2 \mathrm{~mm}-$ $\mathrm{NaH}_{2} \mathrm{PO}_{4}, 2 \mathrm{~mm}-\mathrm{MgSO}_{4}, \quad 1.3 \mathrm{mM}-\mathrm{CaCl}_{2}, \quad 0.01 \mathrm{mM}-$ $\mathrm{MnCl}_{2}, 5 \mathrm{~mm}$-D-glucose and $5 \mathrm{~mm}$-Hepes. Then $2 \mathrm{ml}$ of this buffer containing $0.05 \mathrm{~mm}-\left[{ }^{15} \mathrm{~N}\right]$ aspartic acid was added and the cells were placed in an incubator at $37^{\circ} \mathrm{C}$ for $1 \mathrm{~h}$. The medium was then withdrawn and analysed for its content of $\left[{ }^{15} \mathrm{~N}\right]$ amino acids. To the astrocyte monolayer was added $2 \mathrm{ml}$ of deionized water. The monolayer was scraped vigorously with a rubber spatula and frozen and thawed once to assure lysis of cell contents. The cellular fraction was analysed for [6-amino$\left.{ }^{15} \mathrm{~N}\right]$ adenine nucleotides.

In addition to the incubations with $\left[{ }^{15} \mathrm{~N}\right]$ aspartate, a series of experiments was performed in which the steady-state culture medium was removed, the cells were washed three times with the buffer described above and the culture medium was replaced with buffer containing $10 \mathrm{mM}-\mathrm{NaH}^{13} \mathrm{CO}_{3}$. After $1 \mathrm{~h}$ this medium was removed and analysed for ${ }^{13} \mathrm{C}$ isotopic abundance in aspartate, citrulline, arginine and urea.

\section{Analysis of ${ }^{15} \mathbf{N}$}

${ }^{15} \mathrm{NH}_{3}$ was analysed by a method described in detail elsewhere (Yudkoff et al., 1986). In brief, the technique involves isolation of ammonia from glutamate and glutamine and subsequent enzymic conversion into $\left[{ }^{15} \mathrm{~N}\right]$ glutamate, isotopic abundance in which was measured by gas chromatography-mass spectrometry.

Isotopic abundance in amino acids was determined after formation of the t-butyl dimethylsilyl derivatives (Gaskell \& Pike, 1981). The following ions were utilized for selected ion monitoring by gas chromatographymass spectrometry: $\left.{ }^{15} \mathrm{~N}\right]$ glutamate $\mathrm{m} / \mathrm{z} \quad 433 / 432$, $\left[{ }^{15} \mathrm{~N}\right]$ aspartate $m / z \quad 419 / 418,\left[{ }^{15} \mathrm{~N}\right]$ alanine $\mathrm{m} / z \quad 261 / 260$, $\left[{ }^{15} \mathrm{~N}\right]$ ornithine $m / z 475 / 474,\left[{ }^{15} \mathrm{~N}\right]$ proline $\mathrm{m} / z \quad 287 / 286$, $\left[{ }^{15} \mathrm{~N}\right]$ citrulline $\mathrm{m} / z$ 449/448, $\left[{ }^{15} \mathrm{~N}\right]$ arginine $\mathrm{m} / z$ 358/357, $\left[{ }^{15} \mathrm{~N}\right]$ serine $m / z 391 / 390,\left[{ }^{15} \mathrm{~N}\right]$ glycine $m / z \quad 219 / 218$ and $\left[{ }^{15} \mathrm{~N}\right]$ urea $m / z 232 / 231$.

Isotopic abundances in $\left[2-{ }^{15} \mathrm{~N}\right]$ glutamine, $\left[5-{ }^{15} \mathrm{~N}\right]$ glutamine and [6-amino- $\left.{ }^{15} \mathrm{~N}\right]$ adenine nucleotides were determined by methods described elsewhere (Nissim et al., 1984; Lewis \& Yudkoff, 1985).

\section{Analytical methods}

Amino acids were determined as the $o$-phthalaldehyde derivatives by reverse-phase liquid chromatography (Jones \& Gilligan, 1983). The internal standard was 6-aminohexanoic acid.

Ammonia and ATP were measured enzymically (Lowry \& Passonneau, 1972; Nazar \& Schoolwerth, 1979).

Protein was measured by the Coomassie Blue method (Bradford, 1976).

\section{RESULTS}

\section{Transfer of ${ }^{15} \mathrm{~N}$ to other amino acids, ammonia and adenine nucleotides}

The appearance of ${ }^{15} \mathrm{~N}$ in glutamate and glutamine during incubation with $2.5 \mathrm{mM}-\left[{ }^{15} \mathrm{~N}\right]$ aspartate is shown in Fig. 1. A very high level of enrichment was found in $\left[{ }^{15} \mathrm{~N}\right]$ glutamate, isotopic abundance in which was approx. 37 atom\% excess after $300 \mathrm{~min}$. Much of this nitrogen was transferred to $\left[{ }^{15} \mathrm{~N}\right]$ glutamine, particularly to the amino nitrogen, which is derived directly from $\left[{ }^{15} \mathrm{~N}\right]$ glutamate in the glutamine synthetase reaction. The amide nitrogen becomes labelled from ${ }^{15} \mathrm{NH}_{3}$ and, as shown below, relatively little labelled ammonia was produced. At the conclusion of the experiment, enrichment in $\left[2-{ }^{15} \mathrm{~N}\right]$ glutamine was higher than that of $[5-15 \mathrm{~N}]$ glutamine (18.1 versus 3.1 atom\% excess).

Fig. 2 shows the appearance of ${ }^{15} \mathrm{~N}$ in other amino acids. A substantial transfer of ${ }^{15} \mathrm{~N}$ to alanine occurred, reflecting transamination from glutamate. Indeed, iso-
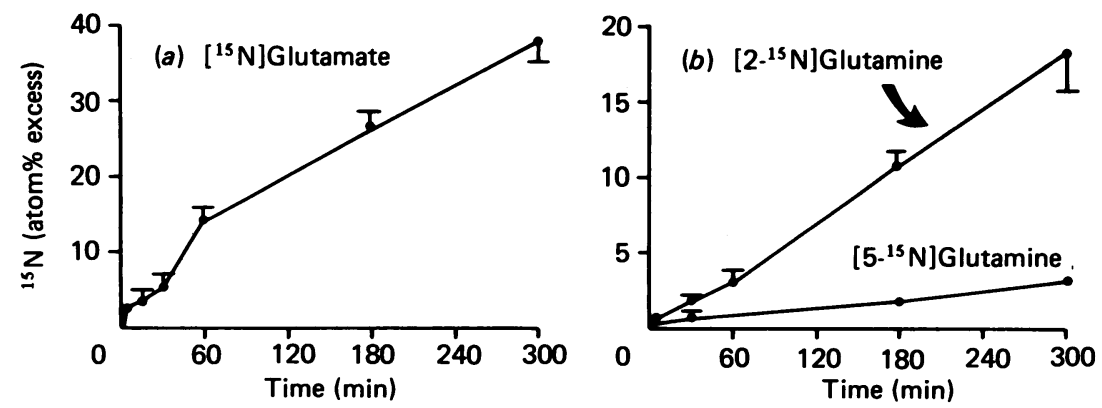

Fig. 1. Plots of isotopic abundance in $(a)\left[{ }^{15} \mathrm{~N}\right]$ glutamate and $(b)\left[2-{ }^{15} \mathrm{~N}\right]$ glutamine and $\left[5-{ }^{15} \mathrm{~N}\right]$ glutamine versus time during incubation of astrocytes with $2.5 \mathrm{mM}-\left[{ }^{15} \mathrm{~N} \mid\right.$ aspartate

Cells were cultured as described in the Materials and methods section. At the indicated times the culture medium was removed and ${ }^{15} \mathrm{~N}$ isotopic abundance in $\left[{ }^{15} \mathrm{~N}\right]$ glutamate and $\left[{ }^{15} \mathrm{~N}\right]$ glutamine was determined as described in the Materials and methods section. Results are means \pm S.D. for three or four experiments. 

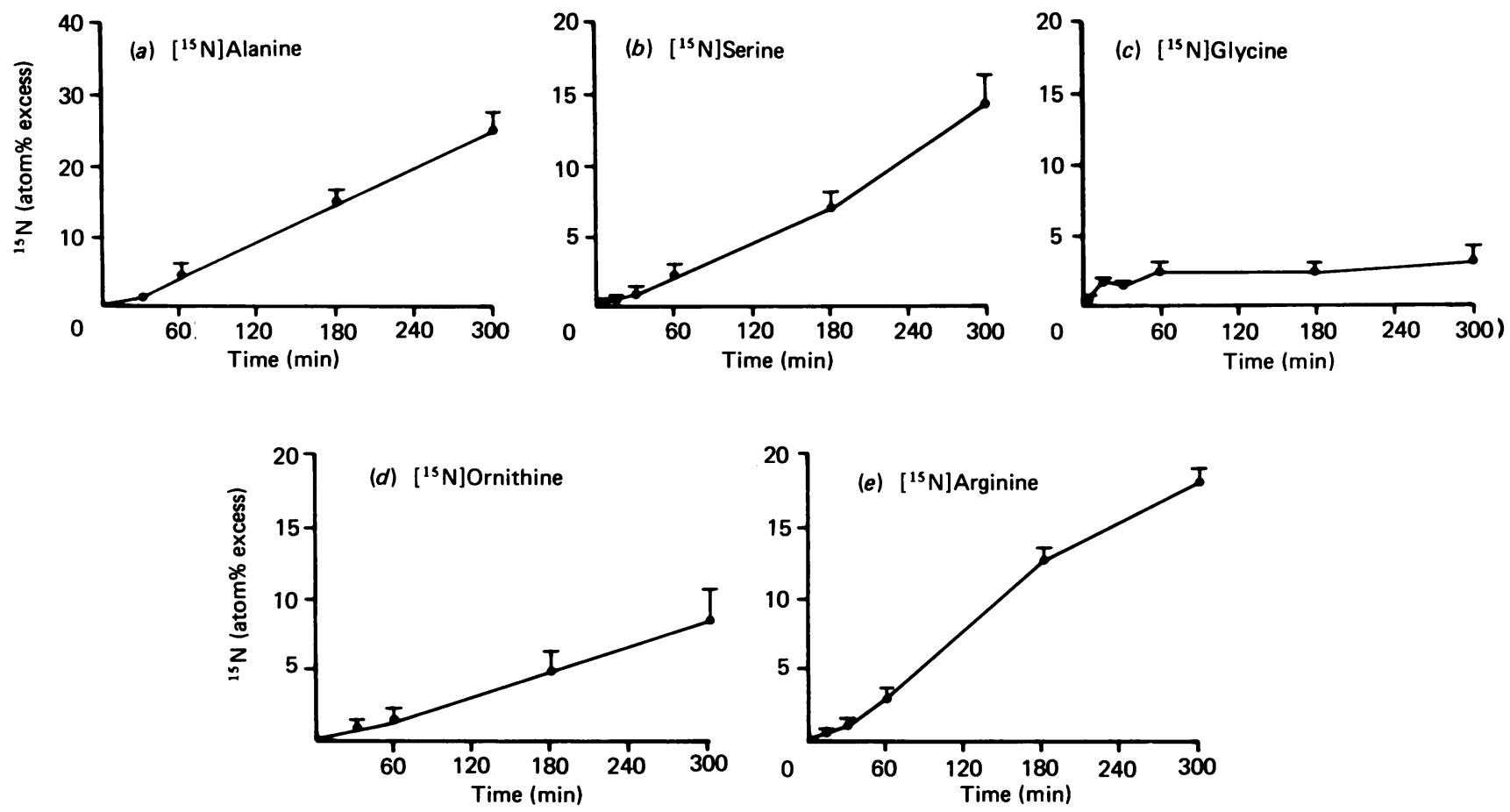

Fig. 2. Plots of isotopic abundance in (a) [ $\left.{ }^{15} \mathrm{~N}\right]$ alanine, $(b)\left[{ }^{15} \mathrm{~N}\right]$ serine, $(c)\left[{ }^{15} \mathrm{~N}\right]$ glycine, $(d)\left[{ }^{15} \mathrm{~N}\right]$ ornithine and $(e)\left[{ }^{15} \mathrm{~N}\right]$ arginine versus time during incubation of astrocytes with $\left.2.5 \mathrm{mM}-{ }^{15} \mathrm{~N}\right]$ aspartate

Cells were cultured as described in the Materials and methods section. At the indicated times the culture medium was removed and ${ }^{15} \mathrm{~N}$ isotopic abundance was determined as described in the Materials and methods section. Enrichment in [ $\left.{ }^{15} \mathrm{~N}\right]$ ornithine and $\left[{ }^{15} \mathrm{~N}\right]$ arginine represents enrichment at a single nitrogen atom. Results are means \pm S.D. for three or four experiments.
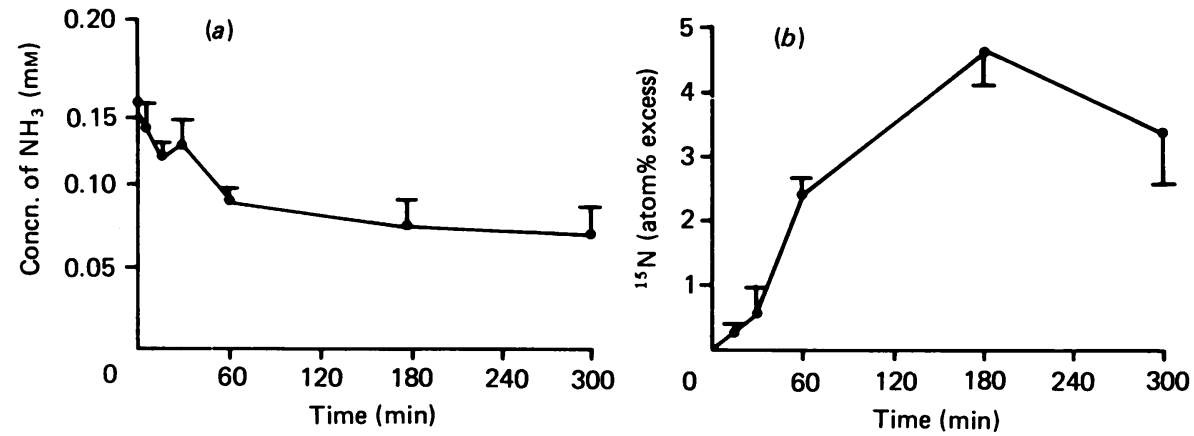

Fig. 3. Plots of (a) concentration of ammonia and (b) isotopic abundance in ${ }^{15} \mathrm{NH}_{3}$ in astrocyte culture medium versus time after the addition of $\left.2.5 \mathrm{mM}-{ }^{15} \mathrm{~N}\right]$ aspartate to the medium

At the indicated times the medium was removed and the ammonia concentration $(a)$ and isotopic abundance in ${ }^{15} \mathrm{NH}_{3}(b)$ were determined as described in the Materials and methods section. Each point is the mean \pm S.D. for three or four determinations.

topic abundance in $\left[{ }^{15} \mathrm{~N}\right]$ alanine exceeded that in $\left[2-{ }^{15} \mathrm{~N}\right]$ glutamine, increasing linearly to about 25 atom $\%$ excess after $300 \mathrm{~min}$. The ${ }^{15} \mathrm{~N}$ label also appeared relatively rapidly in serine, isotopic abundance in which was about 14 atom \% excess at $300 \mathrm{~min}$. Serine could have been synthesized by transamination of either hydroxypyruvate or 3-phosphohydroxypyruvate. Either alanine or glutamate could have served as nitrogen donor (Walsh \& Sallach, 1966). Alternatively, serine nitrogen could be derived from glycine in the serine hydroxymethyltransferase reaction (Daly \& Aprison, 1974). That the latter pathway is not a major route of serine production in astrocytes is indicated by the observation (Fig. 2) that isotopic abundance in $\left[{ }^{15} \mathrm{~N}\right]$ glycine was lower than that in $\left[{ }^{15} \mathrm{~N}\right]$ serine, indicating that a precursor-product relationship between glycine nitrogen and serine nitrogen is not possible. The relatively low level of isotopic enrichment in $\left[{ }^{15} \mathrm{~N}\right]$ glycine probably reflects synthesis via the glycine-cleavage system, in which ${ }^{15} \mathrm{NH}_{3}$ would serve as nitrogen donor (Kikuchi, 1973). As indicated below, ${ }^{15} \mathrm{~N}$ enrichment in ammonia was similar to that of $\left[{ }^{15} \mathrm{~N}\right]$ glycine.

The data in Fig. 2 clearly show that arginine synthesis is an important mechanism for the disposal of aspartate nitrogen in astrocytes. Isotopic abundance in arginine, which increased linearly to 18 atom\% excess by $300 \mathrm{~min}$, reflects condensation with citrulline to form argininosuccinate in the argininosuccinate synthetase reaction 


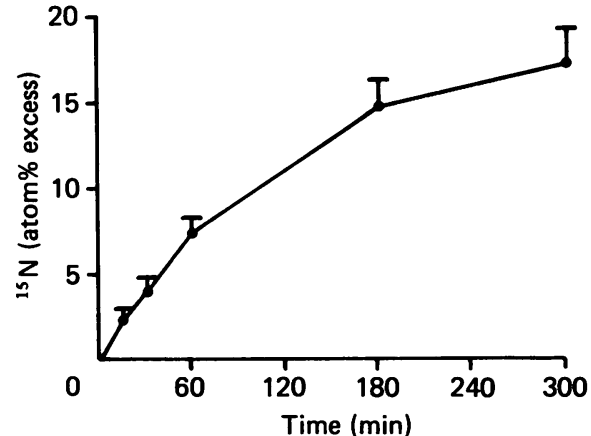

Fig. 4. Isotopic abundance in intracellular $\left[6-a m i n o-{ }^{15} \mathrm{~N}\right]$ adenine nucelotides versus time after the addition of $2.5 \mathrm{mM}$ $\left[{ }^{15} \mathrm{~N}\right]$ aspartate to the steady-state astrocyte incubation medium

Cells were cultured as described in the Materials and methods section. At the indicated times the medium was removed and replaced with $2 \mathrm{ml}$ of deionized water at $40^{\circ} \mathrm{C}$. After the bottom of the culture dish had been scraped with a rubber spatula, the cells were frozen and thawed once to ensure cell lysis. Isotopic enrichment of adenine nucleotides was determined as described in the Materials and methods section. Each point is the mean \pm S.D. for three or four experiments.

and subsequent cleavage of argininosuccinate by argininosuccinase to generate fumarate and arginine. The labelling of arginine probably reflects preferential enrichment of the terminal guanidinium nitrogen atoms rather than the amino nitrogen because isotopic abundance in arginine exceeded that in $\left[{ }^{15} \mathrm{~N}\right]$ ornithine, which contains the amino and non-terminal guanidinium nitrogen atoms of arginine (see Fig. 2). The data in Fig. 2 refer to arginine labelled with ${ }^{15} \mathrm{~N}$ at one of the four nitrogen atoms.

A small amount of urea $(0.1 \mathrm{~mm})$ was present in the steady-state culture medium before the addition of $\left[{ }^{15} \mathrm{~N}\right]$ aspartate, but urea synthesis via the arginase reaction must have been very low, since almost no labelling of urea was noted even though $\left[{ }^{15} \mathrm{~N}\right]$ arginine was so highly labelled.

As already noted, considerable labelling of $\left[{ }^{15} \mathrm{~N}\right]$ ornithine occurred, a level of about 8 atom $\%$ excess being present by $300 \mathrm{~min}$. The $\mathrm{m} / z 475 / 474(M-57)$ ions utilized to determine isotopic enrichment include both ornithine nitrogen atoms, so that it is not possible from the mass-spectrometric data alone to determine the extent of labelling in either atom individually.

The ${ }^{15} \mathrm{~N}$ label was transferred from $\left[{ }^{15} \mathrm{~N}\right]$ aspartate to ${ }^{15} \mathrm{NH}_{3}$, as shown in Fig. 3. Labelling of ammonia increased to a maximal value of approx. 4.7 atom $\%$ excess by $180 \mathrm{~min}$ and declined slightly by $300 \mathrm{~min}$. In contrast, the ammonia concentration in the incubation medium declined after the addition of $2.5 \mathrm{~mm}$ $\left[{ }^{15} \mathrm{~N}\right]$ aspartate, falling to about half the initial value by $180 \mathrm{~min}$. This decrease probably reflected augmented synthesis of glutamine associated with increased availability of glutamate derived from aspartate. We have shown elsewhere that addition of glutamate to the system is associated with a sharp decline in ammonia concentration (Yudkoff et al., 1986).

As indicated in Fig. 4, nitrogen was transferred rapidly from aspartate to the 6-amino position of the adenine nucleotides. Isotopic enrichment in [6-amino- $\left.{ }^{15} \mathrm{~N}\right]$ adenine nucleotides increased rapidly, attaining a value of about 20 atom $\%$ excess by $300 \mathrm{~min}$. The data in Fig. 4, which denote enrichment of the intracellular nucleotide pool, reflect activity of the purine nucleotide cycle (Lowenstein, 1972), involving condensation of $\left[{ }^{15} \mathrm{~N}\right]$ aspartate with IMP to yield adenylosuccinate and subsequent cleavage of this compound to produce [6-amino-15 N]AMP and fumarate. Formation of ADP and ATP proceed much more rapidly than does the transfer of ${ }^{15} \mathrm{~N}$ to the 6-amino position, so that the data reflect labelling of all three adenine nucleotides rather than AMP alone (Krebs et al., 1978). The ATP concentration did not change during the incubation even though labelling at the 6-amino position proceeded rapidly.

\section{Flux from aspartate to other amino acids}

Fig. 5 illustrates the absolute amount (nmol of ${ }^{15} \mathrm{~N} / \mathrm{ml}$ per $\mathrm{mg}$ of protein) of labelled amino acid appearing in the incubation medium. These values represent the product of isotopic abundance (atom $\%$ excess $/ 100)$ and amino acid concentration $(\mathrm{nmol} / \mathrm{mg}$ of protein). Table 1 gives the flux as determined from linear-regression analysis of the data in Fig. 5. These values denote net flux, or the amount of ${ }^{15} \mathrm{~N}$ recovered with time in a given amino acid. Total ${ }^{15} \mathrm{~N}$ flux through an amino acid pool, which was not measured, could have been much greater than net flux.

Much aspartate nitrogen was transferred to [2$\left.{ }^{15} \mathrm{~N}\right]$ glutamine and $\left[5-{ }^{15} \mathrm{~N}\right]$ glutamine, flux to which was about $7.0 \mathrm{nmol} / \mathrm{min}$ per $\mathrm{mg}$ and $1.4 \mathrm{nmol} / \mathrm{min}$ per $\mathrm{mg}$ respectively. The transfer of ${ }^{15} \mathrm{~N}$ from aspartate to arginine was more rapid than the flux to glutamine. Labelling with ${ }^{15} \mathrm{~N}$ at one of the four nitrogen atoms in arginine occurred at a rate of almost $10.0 \mathrm{nmol} / \mathrm{min}$ per $\mathrm{mg}$. As noted above, most of this labelling reflected incorporation of ${ }^{15} \mathrm{~N}$ into the guanidinium group.

Additional repositories of aspartate nitrogen were alanine and serine, flux to which was approx. 3.7 and $0.6 \mathrm{nmol} / \mathrm{min}$ per $\mathrm{mg}$ respectively (Table 1). Appreciable ${ }^{15} \mathrm{~N}$ was transferred also to ornithine. Formation of ornithine labelled at one nitrogen atom occurred at a rate of $0.1 \mathrm{nmol} / \mathrm{min}$ per $\mathrm{mg}$.

Although the formation of $\left[{ }^{15} \mathrm{~N}\right]$ glutamate was very rapid (see Fig. 1), only trace amounts of glutamate could be measured in the incubation medium. Hence the net flux of nitrogen from aspartate to glutamate could not be determined. However, total flux through the intracellular glutamate pool had to equal at least the cumulative flux into glutamine, alanine, serine and ornithine, all of which derive a major portion of their nitrogen from $\left[{ }^{15} \mathrm{~N}\right]$ glutamate.

\section{Metabolism of $\left[{ }^{15} \mathrm{~N}\right]$ aspartate at low concentration}

The studies performed in steady-state culture medium, which contains abundant amino acids, involved the addition of a high $(2.5 \mathrm{~mm})$ concentration of $\left[{ }^{15} \mathrm{~N}\right]$ aspartate. This concentration was necessary in order to attain ${ }^{15} \mathrm{~N}$ labelling of other amino acids at a high enough level in the steady-state medium to be detected accurately by gas chromatography-mass spectrometry. In order to evaluate astrocyte metabolism of aspartate nitrogen at a lower aspartate concentration, the cells were incubated for $1 \mathrm{~h}$ in a buffer containing no amino acids except for $0.05 \mathrm{~mm}-\left[{ }^{15} \mathrm{~N}\right]$ aspartate. Results for ${ }^{15} \mathrm{~N}$ 

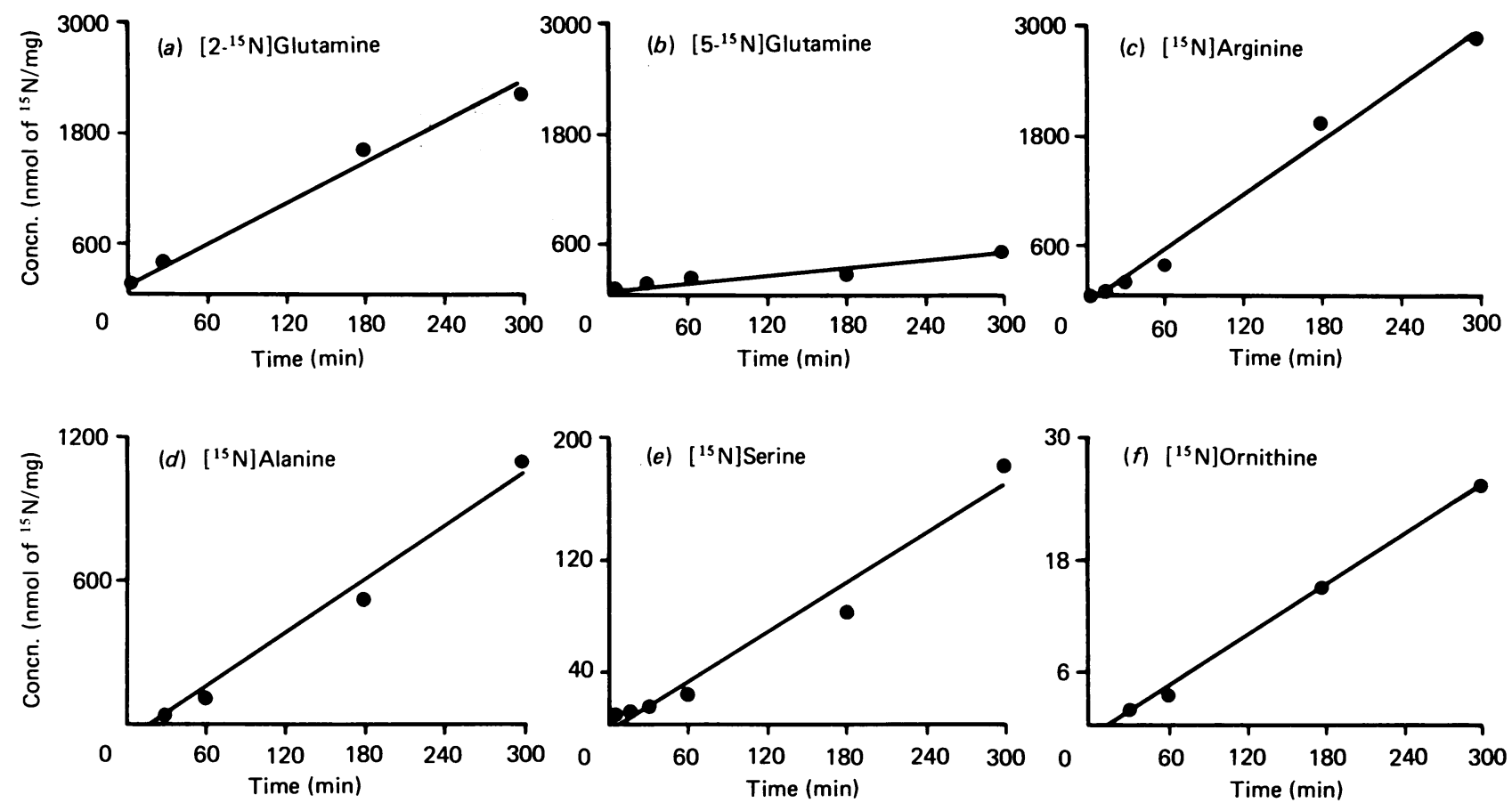

Fig. 5. Plots of concentration of $\left[{ }^{15} \mathrm{~N}\right]$ amino acids in astrocyte culture medium versus time after the addition of $2.5 \mathrm{mM}-\left[{ }^{15} \mathrm{~N} \mid \mathrm{aspartate}\right.$ to the system

At the indicated times the medium was removed and the amino acid concentrations and isotopic enrichment of each amino acid were measured as described in the Materials and methods section. The concentration of each [ $\left.{ }^{15} \mathrm{~N}\right]$ amino acid represents the product of amino acid concentration ( $\mathrm{nmol} / \mathrm{mg}$ of protein) and isotopic abundance (atom $\%$ excess) $/ 100$. The data for $\left[{ }^{15} \mathrm{~N}\right]$ arginine and $\left[{ }^{15} \mathrm{~N}\right]$ ornithine represent the concentration of these two amino acids labelled with ${ }^{15} \mathrm{~N}$ at a single nitrogen atom $(M+1$ species $)$. Each point is the mean \pm S.D. for three or four experiments.

content of the medium are shown in Table 2. The primary metabolic fate of aspartate nitrogen was transfer to alanine, glutamine and arginine. Almost all of the ${ }^{15} \mathrm{~N}$ added to the culture medium was recovered in these amino acids after $1 \mathrm{~h}$. These amino acids also were the principal repositories of aspartate nitrogen when experiments were performed in the presence of $2.5 \mathrm{~mm}$ [15]aspartate. Relatively less ${ }^{15} \mathrm{~N}$ was recovered in arginine than in glutamine with the lower aspartate concentration in the incubation medium. The enrichment of the [6-amino- $\left.{ }^{15} \mathrm{~N}\right]$ adenine nucleotides was much less than that of the amino acids studied.

\section{Incorporation of ${ }^{13} \mathrm{C}$ from $\mathrm{NaH}^{13} \mathrm{CO}_{3}$ into amino acids}

The above data indicated that part of the urea cycle, i.e. the segment from citrulline to arginine, was active in the cultured astrocytes. This segment is cytosolic. The mitochondrial portion of the cycle is not thought to be very active in the brain (Jones et al., 1961; Sadasivudu \& Rao, 1976). However, the fact that astrocytes produce $\left[{ }^{15} \mathrm{~N}\right]$ arginine suggests that they synthesize citrulline, which was not present in the original incubation medium. In order to document citrulline synthesis, the cells were incubated for $1 \mathrm{~h}$ in Hepes buffer, $\mathrm{pH} \mathrm{7.4,} \mathrm{containing}$ $10 \mathrm{~mm}-\mathrm{NaH}^{13} \mathrm{CO}_{3}$. Since the ureido carbon of citrulline is derived from bicarbonate, the presence of ${ }^{13} \mathrm{C}$ labelling of this amino acid indicates activity of the first two steps of the urea cycle. As shown in Table 3, labelling of citrulline and arginine was approx. 25.0 and 9.0 atom\% excess respectively. No ${ }^{13} \mathrm{C}$ enrichment of urea was noted, a finding consistent with the observation that

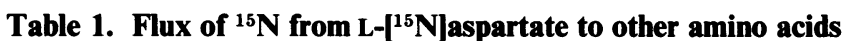

Cells were cultured as described in the Materials and methods section. The flux is derived from linear-regression analysis of the data represented in Fig. 5. Values are normalized to tissue protein. Each value is the mean of four separate determinations.

\begin{tabular}{lc}
\hline & $\begin{array}{c}\text { Flux } \\
\text { (nmol of }{ }^{15} \mathrm{~N} / \\
\text { min per } \mathrm{mg} \\
\text { of protein) }\end{array}$ \\
\hline Amino acid & 7.13 \\
\hline$\left[{ }^{[15} \mathrm{N}\right]$ Glutamine & 1.44 \\
{$[5-15 \mathrm{~N}]$ Glutamine } & 9.93 \\
$\left.{ }^{15} \mathrm{~N}\right]$ Arginine* & 3.71 \\
$\left.{ }^{15} \mathrm{~N}\right]$ Alanine & 0.09 \\
$\left.{ }^{15} \mathrm{~N}\right]$ Ornithine $\dagger$ & 0.59 \\
{$\left[{ }^{15} \mathrm{~N}\right]$ Serine } & \\
inine labelled with ${ }^{15} \mathrm{~N}$ at one nitrogen atom. \\
ithine labelled with ${ }^{15} \mathrm{~N}$ at one nitrogen atom.
\end{tabular}

essentially no $\left[{ }^{15} \mathrm{~N}\right]$ urea was present after incubation of the astrocytes with $\left[{ }^{15} \mathrm{~N}\right]$ aspartate.

Labelling of aspartate was very high, exceeding that observed in citrulline (Table 2). This observation presumably denotes transamination of $\left[{ }^{13} \mathrm{C}\right]$ oxaloacetate formed by the activity of pyruvate carbyoxylase, which in the brain may be restricted to astrocytes (Shank et al., 1981). Thus, although the data indicate that astrocytes 
Table 2. Isotopic abundance in selected metabolites and absolute concentration in incubation medium of $\left.\left.\right|^{15} \mathrm{~N}\right] \mathrm{amino}$ acids after a $1 \mathrm{~h}$ incubation of astrocytes in the presence of $0.05 \mathrm{mM}-\left[{ }^{15} \mathrm{~N}\right]$ aspartate

Astrocytes were cultured as described in the Materials and methods section. The steady-state culture medium was removed and the cells were washed three times with $2 \mathrm{ml}$ of a buffered (pH 7.4) solution containing $138 \mathrm{~mm}-\mathrm{NaCl}, 5 \mathrm{mM}-\mathrm{KCl}, 2 \mathrm{mM}-\mathrm{NaH}, \mathrm{PO}$,

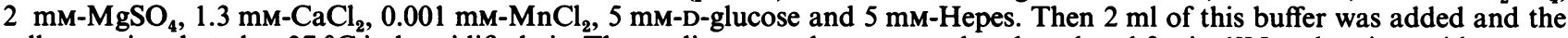
cells were incubated at $37^{\circ} \mathrm{C}$ in humidified air. The medium was then removed and analysed for its ${ }^{15} \mathrm{~N}$ and amino acid content as described in the Materials and methods section. The medium was replaced with $2 \mathrm{ml}$ of deionized water and the bottom of the culture dish was scraped vigorously with a rubber spatula. This suspension was frozen and thawed once to assure complete cell lysis. The intracellular enrichment of $\left[6\right.$-amino- $\left.{ }^{15} \mathrm{~N}\right]$ adenine nucleotide was determined as described in the Materials and methods section.

\begin{tabular}{|c|c|c|c|}
\hline Amino acid & $\begin{array}{c}\text { Isotopic } \\
\text { abundance } \\
\text { (atom } \% \text { excess) }\end{array}$ & $\begin{array}{c}\text { Concentration } \\
\left(\mathrm{nmol} \text { of }{ }^{15} \mathrm{~N} / \mathrm{ml}\right)^{*}\end{array}$ & $\%$ of ${ }^{15} \mathrm{~N}$ added $\dagger$ \\
\hline $\begin{array}{l}{\left[{ }^{15} \mathrm{~N}\right] \text { Glutamate }} \\
{\left[{ }^{15} \mathrm{~N}\right] \text { Alanine }} \\
{\left[2-{ }^{15} \mathrm{~N}\right] \text { Glutamine }} \\
{\left[5-{ }^{15} \mathrm{~N}\right] \text { Glutamine }} \\
{\left[{ }^{15} \mathrm{~N}\right] \text { Arginine } \ddagger} \\
{\left[{ }^{15} \mathrm{~N}\right] \text { Aspartate }} \\
{\left[6-\text { amino- }{ }^{-15} \mathrm{~N}\right] \text { Adenine }} \\
\text { nucleotides }\end{array}$ & $\begin{array}{r}33.2 \pm 10.2 \\
46.4 \pm 4.0 \\
32.3 \pm 2.5 \\
8.4 \pm 4.4 \\
38.7 \pm 2.9 \\
45.6 \pm 6.5 \\
2.1 \pm 3.3\end{array}$ & $\begin{array}{c}0.50 \pm 0.33 \\
7.53 \pm 1.72 \\
13.95 \pm 3.7 \\
3.36 \pm 1.31 \\
6.12 \pm 1.12 \\
1.75 \pm 1.09\end{array}$ & $\begin{array}{r}1.0 \pm 0.7 \\
15.1 \pm 3.4 \\
27.9 \pm 0.1 \\
6.7 \pm 2.6 \\
12.2 \pm 2.2 \\
3.5 \pm 2.2 \\
\end{array}$ \\
\hline
\end{tabular}

Table 3. Isotopic abundance of selected metabolites after a $1 \mathrm{~h}$ incubation of astrocytes in $10 \mathrm{mM}-\mathrm{NaH}^{13} \mathrm{CO}_{3}$

Cells were cultured as described in the Materials and methods section. The incubation medium was removed and the cells were washed three times with $2 \mathrm{ml}$ of a buffered solution ( $\mathrm{pH} 7.4$ ) containing $138 \mathrm{~mm}-\mathrm{NaCl}$, $5 \mathrm{~mm}-\mathrm{KCl}, 2 \mathrm{~mm}-\mathrm{NaH}_{2} \mathrm{PO}_{4}, 2 \mathrm{~mm}-\mathrm{MgSO}_{4}, 1.3 \mathrm{~mm}-\mathrm{CaCl}_{2}$, $0.001 \mathrm{~mm}-\mathrm{MnCl}_{2}, 5 \mathrm{~mm}$-D-glucose and $5 \mathrm{~mm}$-Hepes. Then $2 \mathrm{ml}$ of this buffer containing $10 \mathrm{mM}-\mathrm{NaH}^{13} \mathrm{CO}_{3}$ was added and the cells were incubated for $1 \mathrm{~h}$ at $37^{\circ} \mathrm{C}$. The medium then was withdrawn and analysed for ${ }^{13} \mathrm{C}$ isotopic enrichment in the amino acids indicated. The ions utilized for determination of isotopic abundance were the same as those used to measure ${ }^{15} \mathrm{~N}$ enrichment in the t-butyl dimethylsilyl derivatives (see the Materials and methods section).

\begin{tabular}{lc}
\hline Metabolite & $\begin{array}{c}\text { Isotopic } \\
\text { abundance } \\
\text { (atom\% excess) }\end{array}$ \\
\hline$\left[{ }^{13} \mathrm{C}\right]$ Aspartate & $49.4 \pm 18.9$ \\
{$\left[{ }^{13} \mathrm{C}\right]$ Citrulline } & $24.5 \pm 11.2$ \\
{$\left[{ }^{13} \mathrm{C}\right]$ Arginine } & $8.8 \pm 0.8$ \\
{$\left[{ }^{13} \mathrm{C}\right]$ Urea } & 0
\end{tabular}

avidly utilize aspartate, the cells synthesize aspartate also.

\section{DISCUSSION}

The current data identify three pathways of aspartate nitrogen disposition in astrocytes (see Scheme 1): (I) transamination to glutamate, which is converted into glutamine, alanine, serine and ornithine; (II) condensation with IMP to generate adenylosuccinate, which is hydrolysed to fumarate and AMP via adenylosuccinase;
(III) condensation with citrulline to form argininosuccinate, which is cleaved to arginine.

Transamination from aspartate to glutamate is mediated through aspartate aminotransferase, at least two forms of which are present in brain (Heydorn et al., 1985). The activity of this enzyme is high in astrocytes (Hertz et al., 1983), even exceeding the activity of glutamine synthetase. The cumulative net flux of ${ }^{15} \mathrm{~N}$ into glutamine, alanine, serine and ornithine, each of which is formed from glutamate ${ }^{15} \mathrm{~N}$, is approx. $12.0 \mathrm{nmol} / \mathrm{min}$ per $\mathrm{mg}$ with $2.5 \mathrm{~mm}-\left[{ }^{15} \mathrm{~N}\right]$ aspartate in the incubation medium (Table 1). This value therefore represents a minimal estimate of net ${ }^{15} \mathrm{~N}$ flux from aspartate to glutamate. Indeed, the actual values for net flux would have to be slightly gieater because the data in Table 1 are based only on the isotopic abundance and amino acid concentrations in the medium, not the intracellular component. This factor introduces only a minimal error into the calculation of flux because virtually the entire amino acid content of the incubation system is present in the medium. Thus approx. $99 \%$ of the total glutamine content of the system is in the extracellular fluid, since the concentration of this amino acid is about $0.8 \mathrm{~mm}$ in the $2 \mathrm{ml}$ of medium and $110 \mathrm{nmol} / \mathrm{mg}$ of protein in the cells (Yudkoff et al., 1986), the total protein content of the system being about $0.2 \mathrm{mg}$. A similar calculation indicates that the steadystate medium contains about $99 \%$ of the total alanine and arginine, $98 \%$ of total ornithine and $97 \%$ of total serine.

It must be stressed that the above discussion involves only the net flux of nitrogen, via transamination, from aspartate. The rate of exchange of nitrogen between aspartate and glutamate could exceed net flux. This isotopic exchange was not measured in the current investigation, the object of which was to quantify the net disposition of aspartate nitrogen. 


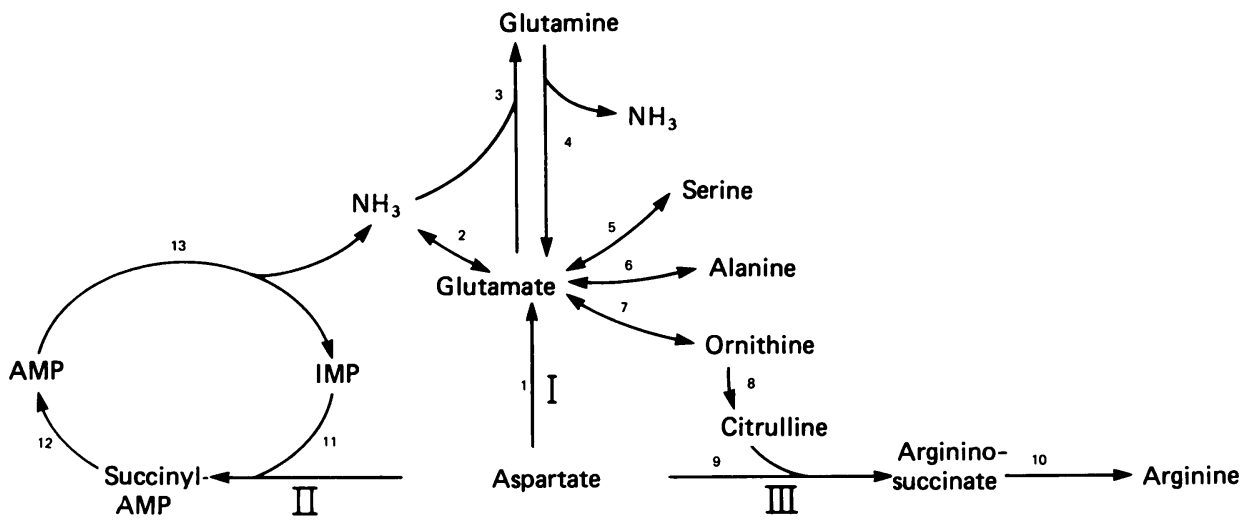

Scheme 1. Diagrammatic representation of the major metabolic pathways for the disposal of aspartate nitrogen in cultured astrocytes

Key to the primary pathways of aspartate nitrogen metabolism: I, the transamination pathway; II, participation in the purine nucleotide cycle; III, condensation with citrulline to produce argininosuccinate, which is cleaved to arginine. Key to enzymic reactions: 1 , glutamate : oxaloacetate transaminase; 2 , glutamate dehydrogenase; 3 , glutamine synthetase; 4 , phosphate-activated glutaminase; 5 glutamate:hydroxypyruvate transaminase; 6, glutamate:pyruvate transaminase; 7 , ornithine 5 -aminotransferase; 8 , ornithine transcarbamoylase; 9 , argininosuccinate synthetase; 10, argininosuccinate lyase; 11, adenylosuccinate synthetase; 12 , adenylosuccinase; 13 , adenylate deaminase.

In the presence of $0.05 \mathrm{~mm}-\left[{ }^{15} \mathrm{~N}\right]$ aspartate, $50 \%$ of ${ }^{15} \mathrm{~N}$ added to the system was recovered in alanine, glutamine and glutamate in the medium (Table 2), again indicating the importance of transamination reactions for aspartate metabolism. The transfer of ${ }^{15} \mathrm{~N}$ from aspartate to these compounds would be even greater if the intracellular pool were included in the calculation. The intracellular fluid contains a greater proportion of total amino acids in these experiments, which are performed in Hepes buffer containing no amino acids at the start of the study, than is true of experiments carried out in the steady-state medium containing a high concentration of amino acids. The fact that only $67 \%$ of ${ }^{15} \mathrm{~N}$ added to the system could be recovered in amino acids of the medium (Table 2) probably reflects the fact that some of the isotope still is resident in the cells, either in the free amino acid pool or incorporated into protein. Some of the 'missing' ${ }^{15} \mathrm{~N}$ also may be present in medium amino acids, which were not measured. The values for isotopic abundance observed in the medium (see Table 2) must reflect intracellular enrichment because the only source of [ $\left.{ }^{15} \mathrm{~N}\right]$ amino acids appearing in the medium would be the intracellular metabolism of $\left[{ }^{15} \mathrm{~N}\right]$ aspartate added to the system. Hence the fact that measurements are made only on the medium in experiments with $0.05 \mathrm{~mm}$ $\left[{ }^{15} \mathrm{~N}\right]$ aspartate would lead to a slight underestimate of the recovery of ${ }^{15} \mathrm{~N}$ but would not affect the values observed for isotopic enrichment. An underestimate of ${ }^{15} \mathrm{~N}$ recovery would only reinforce the conclusion that transamination reactions, the significance of which in astrocytes has been questioned ( $\mathrm{Yu}$ et al., 1982), are essential to the metabolism of aspartate in these cells.

Most $\left[{ }^{15} \mathrm{~N}\right]$ glutamate generated by transamination is converted into $\left[2-{ }^{15} \mathrm{~N}\right]$ glutamine. The fact that labelling of $\left[5-{ }^{15} \mathrm{~N}\right]$ glutamine was considerably lower than that observed in $\left[2-{ }^{15} \mathrm{~N}\right]$ glutamine is consistent with the observation (Figs. 1 and 3) that isotopic abundance in ${ }^{15} \mathrm{NH}_{3}$, the precursor to the amide nitrogen, is less than that in $\left[{ }^{15} \mathrm{~N}\right]$ glutamate, precursor to the amino nitrogen. The astrocytes must have produced ammonia, without which glutamine synthesis is impossible, but the precursor of this ammonia was not highly labelled with
${ }^{15} \mathrm{~N}$. A likely source of ammonia nitrogen is the large pool of glutamine present in the steady-state incubation medium before addition of $\left[{ }^{15} \mathrm{~N}\right]$ aspartate. Glutaminase activity is present in cultured astrocytes (Hertz et al., 1983), and the current data suggest substantial cycling between glutamate and glutamine. Glutamine is not the only source of ammonia. The cells clearly produced ${ }^{15} \mathrm{NH}_{3}$ and incorporated it into $\left[5-{ }^{15} \mathrm{~N}\right]$ glutamine (Figs. 1 and 3 ). Some of this labelled ammonia probably was derived from glutamate in the glutamate dehydrogenase reaction, which in astrocytes can function in the direction of oxidative deamination of glutamate (Yu et al., 1982).

A likely additional source of some ${ }^{15} \mathrm{NH}_{3}$ produced is the adenylate deaminase reaction. As shown in Scheme 1, IMP can condense with aspartate to yield adenylosuccinate, the nitrogen of which ultimately is liberated as ammonia in the purine nucleotide cycle. Isotopic abundance in ammonia was less than that in the 6-amino position of the adenine nucleotides (Figs. 3 and 4), suggesting the possibility of a precursor-product relationship. Thus the cycle could play a role in astrocyte aspartate utilization by providing a mechanism for conversion of aspartate carbon into fumarate and aspartate nitrogen into ammonia. In addition, the cycle helps ensure that adequate ammonia is available to the glutamine synthetase pathway, thereby facilitating the utilization of both aspartate and glutamate.

It is of interest that when the astrocytes were incubated in the presence of a relatively low $(0.05 \mathrm{mM})$ concentration of $\left[{ }^{15} \mathrm{~N}\right]$ aspartate labelling of the [6-amino$\left.{ }^{15} \mathrm{~N}\right]$ adenine nucleotide pool was diminished considerably compared with results obtained in the steady-state culture medium (Fig. 4 and Table 2). The reason for this observation is not apparent from the present data. The steady-state culture medium may have contained hypoxanthine, which the cells would convert first into IMP and then into [6-amino- $\left.{ }^{15} \mathrm{~N}\right]$ adenine nucleotides after condensation with $\left[{ }^{15} \mathrm{~N}\right]$ aspartate. Astrocytes are known to possess abundant hypoxanthine/guanine phosphoribosyltransferase activity (Gruber et al., 1985). Additional study of this potential nexus between the metabolism of nucleotides and aspartate in astrocytes is needed. 
Considerable aspartate nitrogen was recovered in $\left[{ }^{15} \mathrm{~N}\right]$ alanine (Tables 1 and 2). The brain possesses both cytosolic and mitochondrial alanine aminotransferase isoenzymes, the kinetic constants of which should favour alanine formation in the cytosol (Ruscak et al., 1982). Alanine is one of the few amino acids for which net synthesis by the astrocytes can be demonstrated (Yudkoff et al., 1986). Some of this alanine may be converted in neurons into glutamate, thus constituting an alanine-glutamate cycle between neurons and glia that would be analogous to the glutamine-glutamate cycle (Shank \& Aprison, 1981). Alanine is the only amino acid for which a negative arteriovenous difference can be demonstrated when amino acid concentrations of the carotid artery and jugular venous blood are sampled in healthy adults (Deferrari et al., 1981).

The observation (Fig. 2) that astrocytes actively produce $\left[{ }^{15} \mathrm{~N}\right]$ serine and $\left[{ }^{15} \mathrm{~N}\right]$ ornithine is potentially important with regard to neurotransmitter synthesis. Because of its role as the primary donor to the $\mathrm{C}_{1}$ cycle, serine is an important precursor to $S$-adenosylmethionine (Finkelstein \& Harris, 1973). Labelling of ornithine presumably occurred via the mitochondrial ornithine aminotransferase reaction, which is known to be relatively active in astrocytes (Drejer \& Schousboe, 1984). Ornithine may be a precursor to the glutamate utilized for neuronal 4-aminobutyrate synthesis in neurons via a pathway that is subject to feedback inhibition by 4 -aminobutyrate (Shank \& Campbell, 1983).

Hence the data show that astroyctes transfer aspartate nitrogen to several other amino acids, i.e. glutamine, alanine, serine and ornithine, which either are or may be important precursors of neurotransmitters. Additional investigation is indicated to determine the extent to which active cycling occurs between glial metabolism of aspartate and other neurotransmitters. It has been suggested (Shank \& Campbell, 1984) that glia provide, via anaplerotic reactions, much of the carbon utilized by neurons for the synthesis of glutamate released in response to depolarization. The current data suggest a similar role for aspartate nitrogen in the production of neurotransmitters.

We also observed active conversion of aspartate nitrogen into arginine. Indeed, net nitrogen flux from aspartate to arginine exceeded ${ }^{15} \mathrm{~N}$ flux to glutamine in the presence of $2.5 \mathrm{~mm}-\left[{ }^{15} \mathrm{~N}\right]$ aspartate (Table 1). Formation of $\left[{ }^{15} \mathrm{~N}\right]$ arginine was somewhat less active than production of $\left[{ }^{15} \mathrm{~N}\right]$ glutamine when the $\left[{ }^{15} \mathrm{~N}\right]$ aspartate concentration was $0.05 \mathrm{mM}$ (Table 2), but arginine synthesis remained an important metabolic fate of aspartate nitrogen. It is known that the brain possesses high activities of both argininosuccinate synthetase and argininosuccinate lyase (Ratner et al., 1960; Buniatian \& Davtian, 1966; Sadasivudu \& Rao, 1976). The current data suggest that astrocytes are an anatomic locus for much of this activity. Most arginine labelling must reflect enrichment of the guanidinium nitrogen atoms, because isotopic abundance in $\left[{ }^{15} \mathrm{~N}\right]$ arginine exceeded that in $\left[{ }^{15} \mathrm{~N}\right]$ ornithine, which contains the same nitrogen atoms exept for those in the $\alpha$-amino and non-terminal guanidinium groups (Fig. 2). The guanidinium group is derived directly from aspartate nitrogen, which must have been the most highly labelled nitrogen source. Although arginase activity is present in brain (Steward \& Caron, 1977), it must either have been absent or have been inhibited in the current system because no labelled urea was detected when astrocytes were incubated with either $\left[{ }^{15} \mathrm{~N}\right]$ aspartate or $\mathrm{NaH}^{13} \mathrm{CO}_{3}$ (Table 3).

Arginine formation in astrocytes could serve a variety of metabolic functions. First, this pathway provides a means for the net disposal of the nitrogen of aspartate, an excitatory neurotransmitter (Cooper et al., 1982). Indeed, some glutamate nitrogen could be metabolized in a similar fashion after transfer of glutamate nitrogen to aspartate via aspartate aminotransferase. The pathway also might facilitate removal of excess nitrogen via urea formation. Although we could not demonstrate production of labelled urea from labelled arginine, brain urea synthesis has been documented in brain homogenates (Sadasivudu \& Rao, 1976), in cortical slices (Buniatian \& Davtian, 1966), in isolated perfused dog brain (Betz \& Gilboe, 1973) and in the brain of live rats injected either intracisternally or intravenously with $\left[{ }^{14} \mathrm{C}\right]$ arginine (Sporn et al., 1959). Additional investigation seems warranted to determine in which cerebral cellular compartments urea could be produced from arginine, and whether the arginase reaction can become active in astrocytes.

This work was supported by Research Grants HD08536 and NS17752 from the National Institutes of Health. We thank Mrs. Ilana Nissim, Mrs. Denise Denner, Mrs. Janet Stern and Ms. Rosemary Aversa for excellent technical assistance and Ms. Joan Kubinski, Mrs. Theresa Getz and Mrs. Karen Gunn for expert secretarial help.

\section{REFERENCES}

Betz, A. L. \& Gilboe, D. D. (1973) Am. J. Physiol. 224, 580-587

Bradford, M. M. (1976) Anal. Biochem. 72, 248-254

Buniatian, H. Ch. \& Davtian, M. A. (1966) J. Neurochem. 13, 743-753

Cooper, J., Bloom, F. \& Roth, R. (1982) The Biochemical Basis of Neuropharmacology, 4th edn., pp. 249-292, Oxford University Press, New York

Daly, E. C. \& Aprison, M. H. (1974) J. Neurochem. 22, 875-877

Deferrari, G., Garibotto, G., Robarido, C., Ghiggeri, G. M. \& Tizianello, A. (1981) Kidney Int. 20, 505-510

Drejer, J. \& Schousboe, A. (1984) J. Neurochem. 42, 1194-1197

Drejer, J., Larsson, O. M. \& Schousboe, A. (1983) Neurochem. Res. 8, 231-238

Finkelstein, J. D. \& Harris, B. (1973) Arch. Biochem. Biophys. 159, 160-168

Gaskell, S. J. \& Pike, A. W. (1981) Biomed. Mass Spectrom. 8, 125-127

Gruber, H. E., Koenker, R., Luchtman, A., Willis, R. C. \& Seegmiller, J. E. (1985) Proc. Natl. Acad. Sci. U.S.A. 82, 6662-6666

Hertz, L., Yu, A. C. H., Potter, R. L., Fisher, T. E. \& Schousboe A. (1983) in Glutamine, Glutamate and GABA in the Central Nervous System (Hertz, L., Kvamme, E., McGeer, E. G. \& Schousboe, A., eds.), pp. 327-342, Alan Liss, New York

Heydorn, W. E., Creed, J. G., Wada, H. \& Jacobowitz, D. M. (1985) Neurochem. Int. 7, 833-841

Jones, B. \& Gilligan, J. P. (1983) J. Chromatogr. 266, 471-482

Jones, M. E., Anderson, A. D., Anderson, C. \& Hodes, S. (1961) Arch. Biochem. Biophys. 95, 499-507

Kikuchi, G. (1973) Mol. Cell. Biochem. 1, 169-176

Kim, S. U., Stern, J., Kim, M. W. \& Pleasure, D. E. (1983) Brain Res. 274, 79-86

Krebs, H. A., Hems, R. \& Lund, P. (1978) Biochem. J. 176, 733-737

Lewis, S. \& Yudkoff, M. (1985) Anal. Biochem. 145, 354-361 
Lowenstein, J. M. (1972) Physiol. Rev. 52, 384-414

Lowry, O. H. \& Passonneau, J. V. (1972) A Flexible System of Enzymatic Analysis, pp. 153-156, Academic Press, New York

Nazar, B. L. \& Schoolwerth, A. C. (1979) Anal. Biochem. 95, 507-511

Nicklas, W. J. (1983) in Glutamine, Glutamate and GABA in the Central Nervous System (Hertz, L., Kvamme, E., McGeer, E. G., \& Schousboe, A., eds.), pp. 219-231, Alan Liss, New York

Nissim, I., Yudkoff, M. \& Lapidot, A. (1984) Anal. Biochem. $143,14-20$

Norenberg, M. D. (1979) J. Histochem. Cytochem. 27, 756-762

Norenberg, M. D. \& Martinez-Hernandez, A. (1979) Brain Res. 161, 303-310

Ratner, S., Morell, P. \& Carvalho, E. (1960) Arch. Biochem. Biophys. 91, 280-289

Ruscak, M., Orlicky, J., Zubor, V. \& Hager, H. (1982) J. Neurochem. 39, 210-216

Sadasivudu, B. \& Rao, T. I. (1976) J. Neurochem. 27, 785-794

Shank, R. P. \& Aprison, J. (1981) Life Sci. 28, 837-842

Shank, R. P. \& Campbell, G.LeM. (1983) J. Neurosci. Res. 9, 47-57

Received 26 March 1986/14 July 1986; accepted 29 August 1986
Shank, R. P. \& Campbell, G.LeM. (1984) J. Neurochem. 42, 1153-1161

Shank, R. P., Campbell, G.LeM., Freytag, S. O. \& Utter, M. F. (1981) Soc. Neurosci. Abstr. 7, 936

Sporn, M. B., Dingnan, W., Defalco, A. \& Davies, R. K. (1959) J. Neurochem. 5, 62-67

Steward, J. A. \& Caron, H. (1977) J. Neurochem. 29, 657-663

Walsh, D. A. \& Sallach, H. J. (1966) J. Biol. Chem. 241, 4068-4076

Yu, A. C., Schousboe, A. \& Hertz, L. (1982) J. Neurochem. 39, 954-960

Yudkoff, M., Nissim, I., Pleasure, D., Kim, S., Hummeler, K. \& Segal, S. (1983a) in Glutamine, Glutamate and GABA in the Central Nervous System (Hertz, L., Kvamme, E., McGeer, E. G. \& Schousboe, A., eds.), pp. 389-398, Alan Liss, New York

Yudkoff, M., Nissim, I., Kim, S., Pleasure, D., Hummeler, K. \& Segal, S. (1983b) Biochem. Biophys. Res. Commun. 115, 174-179

Yudkoff, M., Nissim, I., Kim, S. U., Pleasure, D. \& Segal, S. (1984) J. Neurochem. 42, 283-286

Yudkoff, M., Nissim, I., Hummeler, K., Medow, M. \& Pleasure, D. (1986) Biochem. J. 234, 185-192 